\title{
Modelos tardomedievales, herencia prehispánica: hacia una intención estilística en la visualidad de Guaman Poma de Ayala
}

\section{Late medieval models, prehispanic heritage: towards a stylistic intention in the visuality of Guaman Poma de Ayala}

CÉCILE ANNE MICHAUD

Pontificia Universidad Católica del Perú

cmichaud@pucp.edu.pe

\section{RESUMEN}

El artículo aborda la cuestión de la presencia de una consciencia artística, y más especificamente de una intención estilistica, en Guaman Poma de Ayala. Se explora esta dimensión a través de dos ejes: su relación a las fuentes visuales tardomedievales, por un lado, y a las prehispánicas, por otro lado. A partir de sus dibujos de la Nueva corónica y buen gobierno (h. 1615-16), asi como de algunas acuarelas específicas presentes en la Historia del origen y genealogía real de los reyes ingas del Piru (desde 1596 hasta después de 1600) de Fray Martín de Murúa, se analiza por qué el autor y artista andino, estando plenamente inmerso en el contexto religioso y cultural virreinal, dirige su atención no a modelos artísticos europeos contemporáneos, como los manieristas, sino a los tardomedievales; también se pone a la luz cómo ciertas características formales de impronta prehispánica serán usadas o abandonadas. Asi, la investigación busca mostrar cómo Guaman Poma supo trascender el proceso mismo de apropiación formal, para encontrar un lenguaje visual a la medida de sus ambiciones históricas y politicas.

Palabras clave: Guaman Poma, visualidad, intención estilistica, grabados tardomedievales, qeros 


\section{ABSTRACT}

This article addresses the issue of the presence of an artistic consciousness - and more specifically of a stylistic intention - in Guaman Poma de Ayala's work. This dimension is explored through two axes: Guaman Poma's relationship with late-medieval visual sources, on the one hand, and to pre-Hispanic ones, on the other. Based on his drawings in the Nueva corónica y buen gobierno (c.161516), as well as some specific watercolor illustrations in Fray Martin de Murúa's Historia del origen y genealogía real de los reyes ingas del Piru (from 1596 until after 1600), it discusses why the Andean author and artist, though fully immersed in viceregal religious and cultural contexts, focused his attention not on contemporary European artistic models, such as the Mannerists, but rather on late-medieval ones. The article also reveals how certain formal characteristics of pre-Hispanic origin were to be used or abandoned. Thus, it seeks to show how Guaman Poma was able to transcend the process of formal appropriation, thus finding a visual language tailored to his historical and political ambitions. Keywords: Guaman Poma, Visuality, Stylistic Intention, Late medieval engravings, Qeros

E ste artículo tiene como objetivo principal analizar una dimensión de varios dibujos de su Nueva Coronica y Buen Gobierno así como de un tipo específico de acuarelas presentes en la Historia del origen y genealogía real de los reyes ingas del Piru, ${ }^{1}$ escrita por el fraile mercedario Martín de Murúa: la presencia de una consciencia artística, y más específicamente de una intención estilística. Esta lo llevó, creemos, a remitirse a ciertas fuentes visuales, dejando de lado las imperantes en el virreinato de aquel entonces. Es así como Guaman Poma, haciendo casi caso omiso de los

${ }^{1}$ El otro manuscrito escrito por Murúa, la Historia general del Piru, llamado también Manuscrito Getty, contiene ante toda evidencia tres ilustraciones de la mano de Guaman Poma y provenientes, según los últimos estudios, de la Historia del origen y genealogía real de los reyes ingas del Piru, o Manuscrito Galvin, que le es anterior. Las evidencias textuales y su documentación se encuentran en Adorno y Boserup 2005: 111-112, 191-198; Adorno y Boserup 2008: 12, 20-23. 
modelos manieristas, fue adoptando una visualidad más bien cercana a las ilustraciones grabadas de libros de fines del siglo XV o inicios del siglo XVI. En esta misma línea, se analizará la influencia que constituyó indudablemente para Guaman Poma la tradición visual prehispánica - especialmente a través de los qeros inca- pero que también será parcialmente abandonada con el tiempo. A través de estas reflexiones, se busca llegar a las causas más profundas de la inconfundible visualidad del autor y artista andino.

Tras una revisión de las numerosas investigaciones que tratan sobre la producción visual de Felipe Guaman Poma de Ayala, actor, testigo y cronista de las primeras décadas del Virreinato del Perú, ${ }^{2}$ hemos llegado a la conclusión de que la reflexión estilística sobre sus dibujos y acuarelas quedó en un estadio de relativo esbozo si la comparamos con los estudios antropológicos e históricos (en primera línea, Juan Ossio, Thomas Cummins, Rolena Adorno, John Murra), semióticos (Adorno, Mercedes López-Baralt), codicológicos (Adorno, Ivan Boserup) y, finalmente, desde la historia del arte, con los estudios iconográficos orientados a la búsqueda de las fuentes europeas que sirvieron de modelo o repertorio iconográfico al autor de la Nueva Corónica (Tom Cummins, José de Mesa - Teresa Gisbert, Maarten van de Guchte y otros). ${ }^{3}$ En este sentido, Guchte, Cummins y Ossio, Augusta E. Holland y Víctor Velezmoro Montes estuvieron entre los pocos investigadores que se interesaron de manera más amplia a la visualidad de Guaman Poma en su esencia plástica y formal. ${ }^{4}$

${ }^{2}$ No regresaré en este artículo sobre la vida de Guaman Poma, sobre la cual existe una amplia bibliografía. Véase en prioridad, para las referencias más actualizadas de su biografía, Adorno 1993, 1995 y 2013; las introducciones y prólogos a las siguientes ediciones de la Nueva corónica y buen gobierno: Guaman Poma de Ayala 1980, 1993, 2015 y 2017; además, Pease 1989 y 2010, Adorno 1992, y finalmente Adorno y Boserup 2015.

3 Para un estado de la cuestión bastante exhaustivo de la fortuna crítica de los manuscritos de Guaman Poma, véase Velezmoro Montes 2012: 35-98.

${ }^{4}$ La propuesta de Guchte (1992) constituye un punto de partida esencial para las reflexiones desarrolladas en el presente artículo. Para estudios estilísticos y plástico-formales, véase Cummins 2008; Cummins, Engel, Anderson y Ossio 2014; Holland 2008 y Velezmoro Montes 2012. El libro de Holland se dedica, sobre este tema, al estudio de las distintas 
Nos preguntamos entonces, como es legítimo, por qué el estudio del estilo de Guaman Poma había quedado un tanto relegado. Tenemos ahí una primera hipótesis: el enriquecimiento progresivo de los modos de hacer historia del arte, hasta llegar al más reciente concepto de Visual Studies - que busca asociar la historia del arte con los estudios culturales, la teoría crítica y otras disciplinas como la filosofía y la antropologíadesplazó poco a poco el lugar de los estudios estilísticos; es decir, esta visión cada vez más interdisciplinaria del estudio de las artes visuales ha probablemente contribuido a la relegación paulatina, en general, del estudio del estilo.

El estudio renovado de los aspectos estilísticos, no obstante, puede integrarse perfectamente en estos paradigmas epistemológicos más recientes. La visualidad de un artista es, pues, en primer lugar, el producto de una selección de formas, tal como lo destacaron Ernst Gombrich o Claude Lévi-Strauss: para el primero, esta selección de formas constituye «el pivote de toda la teoría de la expresión», 5 mientras que el segundo, al final de la Vía de las máscaras escribe:

esperamos haber demostrado que una máscara no es ante todo lo que representa sino lo que transforma, es decir elige no representar. Igual que un mito, una máscara niega tanto como afirma; no está hecha solamente de lo que dice o cree decir, sino de lo que excluye. ¿No ocurre otro tanto con toda obra de arte? [...] La originalidad de cada estilo no excluye, así, los préstamos; se explica más bien por un deseo consciente o inconsciente de afirmarse diferente, de escoger entre todas las posibilidades algunas que al arte de los pueblos vecinos ha rechazadom. ${ }^{6}$

perspectivas espaciales presentes en la Nueva corónica y al uso plástico de la tinta por Guaman Poma, entre otros. La tesis doctoral de Velezmoro Montes, cuyo tema central son precisamente los aspectos estilísticos de Guaman Poma, se concentra por su parte más bien en el análisis de un repertorio de formas, en vista a la identificación de varias manos y por tanto a la hipótesis de un taller.

5 «To quote the formulation of a linguist, 'The pivot of the whole theory of expressiveness is the concept of choice. There can be no question of style unless the speaker or writer has the possibility of choosing between alternative forms of expression» (Gombrich 2009: 130).

${ }^{6}$ Levi-Strauss 1985: 124. Si bien no pretendemos que Guaman Poma haya tenido 
La comprensión profunda de la intención estilística de un artista solo se podrá lograr, por tanto, a través de una mirada directamente conectada a su entorno cultural.

Una segunda hipótesis es que los contenidos textuales y narrativovisuales asociados a Guaman Poma, y en particular los de la Nueva corónica y Buen Gobierno, son tan abrumadores por su riqueza y complejidad, que los aspectos formales terminaron relegados sobre la base de una historiografía primogénita que estuvo lejos de apreciar, a nivel artístico y estilístico, el trabajo del autor indígena.

De facto, las primeras generaciones de investigadores usan los peores calificativos para la Nueva Corónica, empezando con un juicio despectivo sobre el texto mismo: «indiana algarabía» (Marcos Jiménez de la Espada), «a jumble of superstitious and cabalistic nonsense» («una maraña de absurdos supersticiosos y cabalísticos», Philip Ainswort Means), «orma bárbara y confusa» (Raúl Porras Barranechea). ${ }^{7}$ Este desprecio se traslada también a los dibujos, aunque también algunos les reconocen ya algunas cualidades artísticas. ${ }^{8}$

En otras palabras, para varios de los primeros investigadores de Guaman Poma, el estilo de inspiración tardomedieval de la Nueva corónica habría sido el resultado de un artista conocedor de fuentes europeas, pero muy limitado en su formación, incapaz de manejar la perspectiva u otros tipos de recursos plásticos característicos del paradigma renacentista, paradigma ante toda evidencia muy preciado por aquellos estudiosos.

Posiblemente, no se reparó lo suficiente en que, en cuanto al ámbito pictórico, lo que llegó al Virreinato del Perú en el último tercio del siglo

voluntad de crear un estilo comunitario, en el sentido que lo teoriza Levi-Strauss, sí la cita nos parece pertinente en relación a la idea de selección consciente de formas.

${ }^{7}$ Estas citas y otras se encuentran como recuento historiográfico en Adorno 1974, Guaman Poma de Ayala 2015, I: 12 y 2017, I: 10.

8 «notables cualidades en la composición de los cuadros y, sobre todo, mucho realismo en la manera de tratarlos. Es muy observador, todo le interesa y, particularmente, los tipos sociales tan diversos del Perú colonial» (Chevalier 1944: 527); «un talento que no es, para nada, mediocre, aunque cuando carezcan de proporciones anatómicas» (Pietschmann 1968: xxi); «vitalidad expresiva, movimiento y composición». Estas citas y otras se pueden encontrar en el recuento historiográfico de Velezmoro Montes 2012: 36-41. 
XVI fueron artistas italianos representantes de un manierismo teñido; denominado por Sydney J. Freedberg como la contramaniera, es decir, un manierismo tardío, postridentino, marcado, por tanto, no solamente por la voluntad de un regreso a cierto naturalismo, sino también por cierta dulzura rafaelesca, susceptible de conmover y enternecer al feligrés. ${ }^{9}$ En este sentido, es importante tener presente que los artistas italianos de aquella generación que llegaron al Perú no traían las preocupaciones de sus antecesores; es decir, la precisión de la anatomía o el manejo de la perspectiva matemática. La consecuencia directa resultó en que los artistas locales de aquel último tercio del siglo XVI, muy aparte de su propia tradición visual, tuvieron desde un inicio un tipo de modelos pictóricos europeos bastante alejados de los netamente renacentistas. Pero Guaman Poma, a diferencia de sus contemporáneos, dejó claramente de lado estos modelos manieristas, ${ }^{10}$ sea de la producción local de los maestros italianos y sus primeros seguidores locales, o de las imágenes grabadas que llegaron por millares de Europa para fines evangelizadores como hojas sueltas o publicadas en los numerosos libros que traían las órdenes religiosas o intelectuales, así como también mediante el comercio (figs. 1-2).

Guaman Poma, tal como se demostró ampliamente, fue un hombre sumamente leído ${ }^{11}$; pero estuvo habitado además, creemos, por una

${ }^{9}$ Véase Freedberg 1978. Véase también, para el traslado del concepto de Contramaniera al arte virreinal, Stastny 1980.

${ }^{10}$ Esta constatación la hace Teresa Gisbert, sin por tanto explicarla. Al respecto, véase Gisbert 1992: 80-81.

${ }^{11}$ Además de la Biblia, del Tercer Catecismo y otros libros religiosos —y aparte de las propias acotaciones de Guaman Poma - se ha investigado sobre el conocimiento que tenía el autor andino de la literatura cronística del siglo XVI así como de tratados de astrología y cosmografía como el Repertorio de los tiempos de Hierónimo de Chaves, del cual el autor andino se habría inspirado para sus Edades del Mundo. Para el uso de las fuentes escritas y visuales europeas y su subordinación, o no, al pensamiento andino del autor —eje de muchos debates en las últimas décadas — véase, entre otros, Wachtel 1971, Adorno 1978 y Cabos Fontana 2000; sobre el Repertorio de los tiempos de Chaves como posible fuente textual, véase Fleming 1994, Barnes 1995 y Plas 1996; sobre otro Repertorio de los Tiempos anónimo, Gonzáles-Díaz 2012. Para una visión sintética del caso de Guaman Poma en el marco de la relación de la élite nativa con los libros, véase Guibovich 2017: 190-191. 
intención estilística, siempre conectable con sus procesos de creación y la evolución de su visualidad. Por tanto, el análisis atento y lúcido de esta nos debería permitir ir más allá de la simple taxonomía: hacia la relación de Guaman Poma con su entorno visual inmediato, su cultura visual, así como sus propósitos como autor y artista.

Fig. 1. Bernardo Bitti, Coronación de la Virgen. Óleo sobre lienzo. 15751582. Iglesia de San Pedro, Lima.

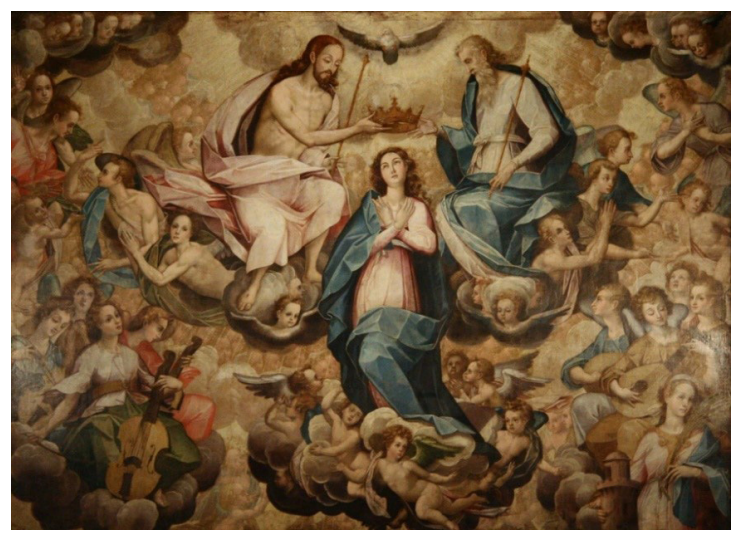

Fig. 2. San Pablo. Calcografía. Libro de Sermones y Epistola de San Pablo. Venecia, 1587. Archivo Arzobispal de Ayacucho.

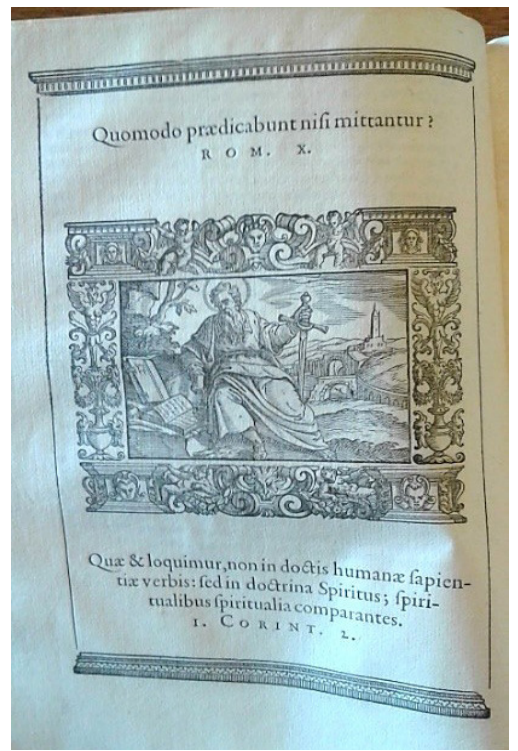


Respecto a esta intención estilística, queremos plantear dos ejes de reflexión: ¿Por qué las imágenes de Guaman Poma nos ofrecen mayormente un estilo o una visualidad que recuerda más, por lo menos desde una perspectiva occidental, a grabados europeos de fines del siglo XV o inicios de siglo XVI, que al manierismo italiano en todas sus variantes (incluyendo a la contramaniera de un Bernardo Bitti, que le es contemporáneo y hasta lo rodea físicamente) de Lima a Cusco y Arequipa, e incluso en la propia Huamanga, su provincia de origen ${ }^{12} \mathrm{Y}$ por otro lado, ¿en qué medida se impone la tradición visual andina prehispánica en el imaginario artístico de Guaman Poma? Esta segunda pregunta se hace particularmente sugerente al observar las acuarelas de Guaman Poma - ¿y un posible taller?- ${ }^{13}$ en la Historia del origen y genealogía real de los reyes ingas del Piru, también llamada Manuscrito Galvin ${ }^{14}$, concluida por Fray Martín de Murúa unos quince a veinte años antes de la Nueva Corónica, y que narra, como su título indica, la historia de los Incas. En este caso, llama poderosamente la atención el paralelo que se puede establecer entre imágenes de tradición prehispánica y en especial los qeros, y ciertas ilustraciones del Manuscrito Galvin. ${ }^{15}$ Trataremos de aportar algunos elementos de respuesta a estas dos interrogantes en las líneas que siguen.

\section{MODELOS TARDOMEDIEVALES: ¿BUSCANDO UNA VISUALIDAD DEL PASADO?}

La hipótesis de una selección consciente de formas y modelos visuales se ve impulsada por la formación misma de Guaman Poma. Fue un hombre ante toda evidencia muy bien educado intelectual, religiosa y artísticamente, lo cual nos conduce lógicamente a pensar que su

12 Para la cronología de las estancias de Bitti en las diversas ciudades del Virreinato, véase Mesa y Gisbert 1974: 24-114 y 1983.

${ }^{13}$ Véase Ossio 1998: 278 y 2004: 49; Martínez Sagredo 2011: 106. Para una fortuna crítica sobre el tema de un taller familiar y conclusiones propias, véase Velezmoro Montes 2012: 1-2, 69 y 234.

${ }^{14}$ Murúa 2004.

${ }^{15}$ Sobre la existencia de vínculos entre la visualidad de Guaman Poma y los qeros, véase Murúa 2004: 28, fig. 4; Cummins 1988: 355; Gisbert 1992: 82, figs. 48-49. 
capacidad de decisión, de juicio y, por tanto, de selección no puede ser subestimada. Sus propias afirmaciones y la información documental que ha llegado a nuestros días nos lo presentan como asistente y/o intérprete de Cristóbal de Albornoz en sus misiones de extirpación de idolatría en Huamanga, pero también cercano a otras figuras como Diego Beltrán de Caicedo (llamado «Padre» por el mismo Guaman Poma ${ }^{16}$ ), quien fue administrador del Hospital de Naturales en Huamanga. En este círculo cercano, estuvo también el Padre Beltrán de Saravia, sacerdote doctrinero del repartimiento de Atunsoras y vicario general de Andamarcas, Soras, Lucanas en Huamanga. Por supuesto, Fray Martín de Murúa (quien fuera corregidor del pueblo de Yanaca, «cura doctrinante de Pocouanca, Pacica, Pichiva» según el mismo Guaman Poma y con quien estuvo trabajando el artista andino de muy cerca en el Manuscrito Galvin) fue una figura de primer orden para su cultura intelectual, como lo demuestran los diversos préstamos textuales que hace Guaman Poma en su Nueva corónica. También su (¡supuesto?) hermanastro el sacerdote ermitaño Martín de Ayala, quien según el cronista trabajó en el Hospital de Naturales de Huamanga además de servir al obispo Fray Gregorio de Montalvo, obispo del Cusco entre 1590 y 1592, contribuyó ampliamente a su educación religiosa. ${ }^{17}$

Igualmente, muy cercano estuvo Jerónimo de Oré, franciscano nacido en Huamanga en una familia cercana a Guaman Poma y que este admiraba mucho. ${ }^{18} \mathrm{Al}$ respecto, es interesante mirar cómo la imagen de la Virgen con el Niño que ilustra la portada del Symbolo Cathólico Indiano de Oré - publicado en Lima por el primer impresor de la ciudad, Antonio Ricardo, en el año 1598- se inscribe en un patrón estilístico cercano a lo tardogótico

${ }^{16}$ (Egenplo del Padre Icaicedo) PENITENCIA INRI padre ayala diego beltran de caysedo administrador del hospital conpanero del padre Ayala en la ciudad de guamanga» (Guaman Poma de Ayala 1980, I: 15).

${ }^{17}$ Véase Ossio 2008 : 22, 52, 62, 71-72, 116-117.

${ }^{18}$ Adorno propone que «Oré y los otros autores [mencionados por Guaman Poma] no fueron solamente los héroes literarios de Guaman Poma sino sus únicos héroes, en un ambiente que consideraba, por los ańos de 1615 , como desesperadamente corrupto» (1978: 155-156). Véase también Albó 1998: 338. 


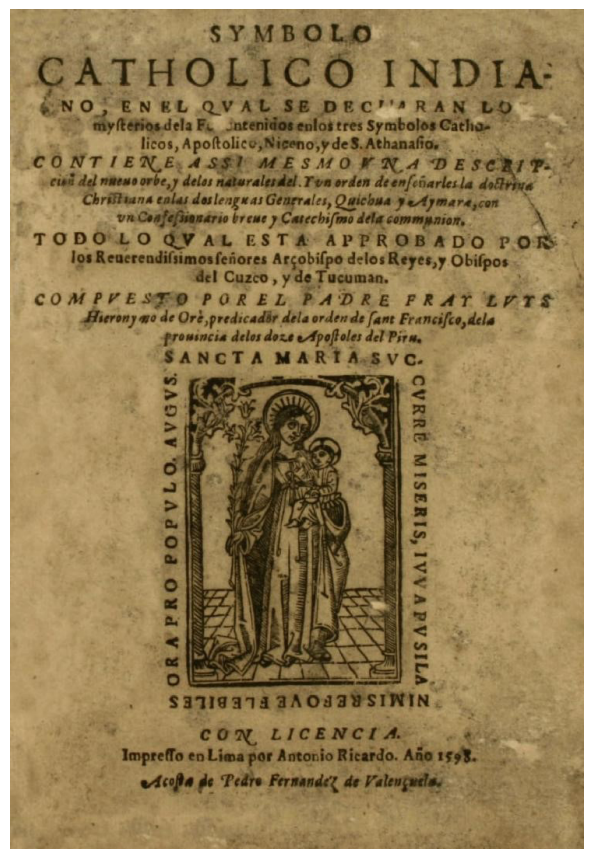

Fig. 3. Fray Luis Jerónimo de Oré, Portada del Symbolo Cathólico Indiano. Lima: Antonio Ricardo, 1598.

(fig. 3). Esta ilustración recuerda a su vez al Santo Domingo de la portada de, por ejemplo, la Doctrina Cristiana breve de Fray Domingo de la Anunciación, publicada en 1565 en México por Pedro Ocharte, a quien Ricardo había conocido en Lyon, antes de viajar juntos a Valladolid. Una comparación similar se podría hacer también con el frontispicio de la Regla christiana breve de Fray Juan de Zumarraga, publicada por el fundador de la imprenta en Nueva Espańa, Juan Pablos, en 1547. En este contexto, el uso de modelos tardomedievales se inscribe ante toda evidencia en un contexto peruano y americano más amplio, y no es de excluir que Guaman Poma haya conocido algunas de estas publicaciones novohispanas. ${ }^{19}$

${ }^{19}$ Acerca de Antonio Ricardo y Pedro Ocharte, véase Eguiguren 1945: 334-335. Sobre la circulación de grabados en América a partir de las planchas usadas por la casa de imprenta sevillana Cromberger instalada en México, véase Griffin 1989. Para el caso particular del fundador de la imprenta en Nueva España, el italiano Juan Pablos (Giovanni Paoli), quien fuera empleado de Johannes Cromberger y mandado por él a Nueva España a partir del 1539, véase Grañen Porrúa 2011. 
Respecto a los jesuitas, quienes como orden religiosa recibieron la profunda admiración de Guaman Poma, solo dos son mencionados en la Nueva corónica ${ }^{20}$ : uno es un cierto Padre Santiago, descrito como santo hombre tal como todos los padres de esta orden ${ }^{21}$; el segundo es el Padre Acosta, precisamente por los libros que este escribió:

y después se hizo otro libro escrita del padre maystro juzepe de acosta rretor de la conpania de jesus escrita de natura de nobi urbis y de procuranda y cartilla, caticismo preparacion y libro confecionario y doctrina en la lengua quichiua, aymara proueyda en el santo conçilio confirmado de su magestad en la dicha ciudad y corte de los rrey de lima. ${ }^{22}$

Sin pretender con esta lista a la exhaustividad histórica, asumimos que es a través de estos actores y otros, así como por su formación en sí y las actividades de evangelización a las cuales participó, que Guaman Poma tuvo libre y amplio acceso a numerosas ilustraciones impresas de carácter mayormente sagrado. Su sola condición de intérprete en las misiones de extirpación de idolatrías, con un cargo probablemente similar al de un fiscal doctrinal, esboza los contornos de un hombre versado no solamente en el catecismo y en la teología, sino también en las humanidades, con un privilegiado acceso a libros ilustrados y grabados, fuesen estos consultados por él en bibliotecas o expuestos ante los indígenas para la evangelización. Cabe recalcar aquí que la hipótesis, varias veces propuesta, de la existencia de una biblioteca privada de Cristóbal de Albornoz como fuente directa de Guaman Poma, está sujeta a duda. ${ }^{23}$

Si bien los conocimientos sobre la formación y actividad artística de Guaman Poma fuera de la Nueva corónica y del Manuscrito Galvin (y del Manuscrito Getty a partir del Galvin) son casi inexistentes, su rica

${ }^{20}$ Ib.: 339.

${ }^{21}$ Guaman Poma de Ayala 1980, II: 603.

${ }^{22}$ Guaman Poma de Ayala 1980, III: 997.

${ }^{23}$ Pedro Guibovich argumenta, a diferencia de John V. Murra (Adorno, Cummins et al. 1992: 61), que es poco probable que Albornoz poseyera una biblioteca privada, habiendo sido él titular del solo grado de bachiller y no de doctor. Agradecemos su comunicación oral de marzo de 2017. Sobre las pruebas documentales acerca del grado y las competencias de Albornoz, véase Guibovich 1991: 217-219. 
cultura visual, en cambio, es evidente, aun cuando no existen pruebas documentales de su uso de grabados tardomedievales. ${ }^{24}$ Así, por ejemplo, no encontramos en los archivos y bibliotecas de Huamanga ninguna huella de la Biblia Germanica, del Speculum Humanae Salvationis, de la Vita Christi Cartuxano o del Cordiale Quatur novissimorum, para citar solo algunas ediciones muy populares de fines del siglo XV o de inicios del siglo XVI. ${ }^{25}$ Sin embargo, conjuntamente con los conocimientos sobre la formación de Guaman Poma, el análisis de las imágenes permite corroborar la hipótesis de una selección de formas. Para entender este

${ }^{24}$ Teresa Gisbert propone que Guaman Poma haya sido formado en una «escuela de arte» ("crafts school») para nativos en el Cusco (Gisbert 1992: 86). Por otro lado, los Mesa Gisbert atribuyeron a Guaman Poma una pintura mural que representa a la Virgen de la Merced en la iglesia San Cristóbal en Cusco. Véase Mesa y Gisbert 1982, I: 87 y Gisbert 1992: 86, fig. 53.

${ }^{25}$ Pudimos revisar la gran mayoría de los libros religiosos e ilustrados, anteriores a 1600, tanto en el Archivo Arzobispal de Huamanga, donde están conservados los libros del antiguo colegio jesuita de la ciudad, como en la Biblioteca del Convento de San Francisco de Asís de Huamanga. Dimos la prioridad a estos dos fondos bibliográficos por ser los jesuitas y los franciscanos dos órdenes de las cuales estaba muy cercano Guaman Poma (además de los Ermitaños, por su hermanastro). No encontramos ningún incunable o libro, ilustrado o no, anterior a 1534. Todas las ilustraciones localizadas en los libros religiosos del siglo XVI e inicios del siglo XVII eran de estilo netamente manierista, salvo una xilografía de corte un tanto más tardomedieval, representando una Crucifixión, en un Evangelio de san Juan publicado en 1562. Es probable que, por ser los libros ilustrados, y más aún los incunables, los más valiosos en términos mercantiles, precisamente estos hayan sido sustraídos a lo largo de los siglos. Es así como durante nuestra revisión, hemos advertido que varios frontispicios fueron arrancados o incluso blasones cortados con tijera. Agradecemos aquí muy sinceramente al señor Cristian Zalcedo, responsable del Archivo Arzobispal de Huamanga, y al padre Víctor Conce, Padre Guardián del Convento de San Francisco de Asís de Huamanga, por habernos permitido el acceso sin restricción a sus fondos bibliográficos más antiguos.

${ }^{P}$ or otro lado, falta un estudio de largo aliento en todas las bibliotecas conventuales del país para cuantificar y analizar la presencia en el Perú de incunables europeos. Sobre la producción, circulación de libros y la conformación de bibliotecas en la América y el Perú virreinal, véase García Aguilar y Rueda Ramírez 2014 y, en dicha publicación, especialmente Guibovich 2014. Sobre la presencia de literatura europea en el Virreinato del Perú, véase, entre varias publicaciones de este autor, Leonard 2004. Sobre las bibliotecas privadas en el Perú virreinal, véase Hampe 1996. Sobre la relación de la élite nativa al libro, véase Guibovich 2017. 
fenómeno, se debe mirar por un lado las características visuales de los grabados manieristas (o contramanieristas) presentes en el Perú, marcados por un profuso repertorio ornamental, una gestualidad delicada y algunas posiciones rebuscadas (figs. 2, 4); luego, confrontar estas características visuales con grabados tardomedievales (figs. 5, 7); para finalmente comparar ambos tipos de obras con las imágenes pomanianas (figs. 6, 10). En la secuencia de imágenes en la que confrontamos los tres tipos de obras (figs. 4-6), podemos notar cómo Guaman Poma parece haber absorbido ciertos elementos de los grabados del siglo XVI, como por ejemplo el juego del viento en unos cabellos o cierta soltura en los pliegues de ropajes; pero en la manera como la figura ocupa la superficie de la página, en la monumentalidad y sencillez compositiva, se le reconoce una mayor cercanía con los grabados tardomedievales.

Lo que también se hace notable en estas comparaciones es que en las biblias, y en general en los libros tardomedievales, las ilustraciones funcionan como viñetas (fig. 7), mientras que en los libros de la segunda mitad del siglo XVI e inicios del XVII ya se pueden encontrar escenas de plena página (fig. 8). Es probable que ya Murúa, con o sin la sugerencia de Guaman Poma, haya decidido inspirarse de los libros ilustrados más recientes para las escenas de su Historia del origen y genealogía real de los reyes ingas del Perú, ofreciendo así por primera vez, por lo menos de lo que conservamos en el Virreinato del Perú, unas imágenes que ocupan toda la página, procedimiento que será retomado por Guaman Poma en su Nueva corónica (figs. 9-10). Cabe postular, entonces, que la visualidad de inspiración tardomedieval ha sido trasladada a un formato más contemporáneo.

Ahora bien, ¿qué empujó entonces a Guaman Poma a dejar de lado a sus contemporáneos manieristas y a las fuentes grabadas del mismo corte, para concentrar su mirada en fuentes europeas grabadas más tempranas, que van esencialmente del último tercio del siglo XV al primer tercio del siglo XVI? ${ }^{26}$ ¿Qué razones pueden explicar esta selección?

${ }^{26}$ El primero en llamar la atención, de manera más extensa y detallada, sobre este fenómeno fue Maarten van de Guchte (1992), en un importante ensayo sobre las fuentes grabadas tardomedievales de Guaman Poma. 


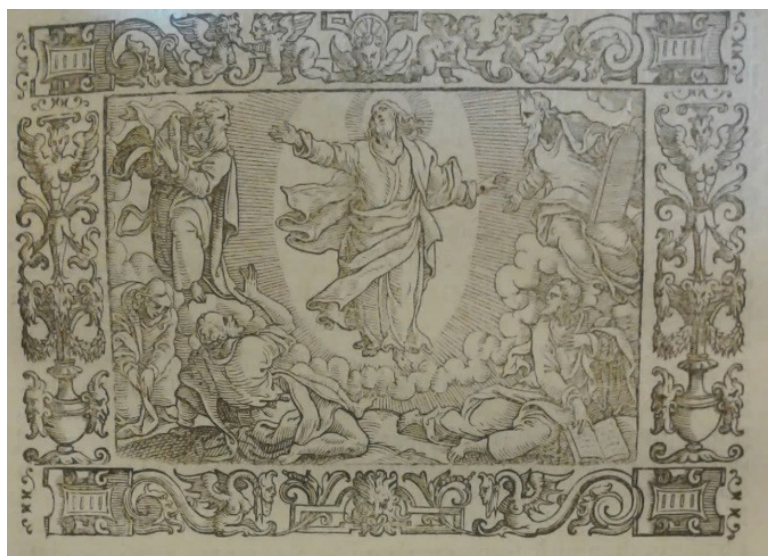

Fig. 4. Transfiguración.

Calcografía. Libro de Sermones y Epistolas de San Pablo. Venecia, 1587. Archivo Arzobispal de Ayacucho. Fotografía de la autora.

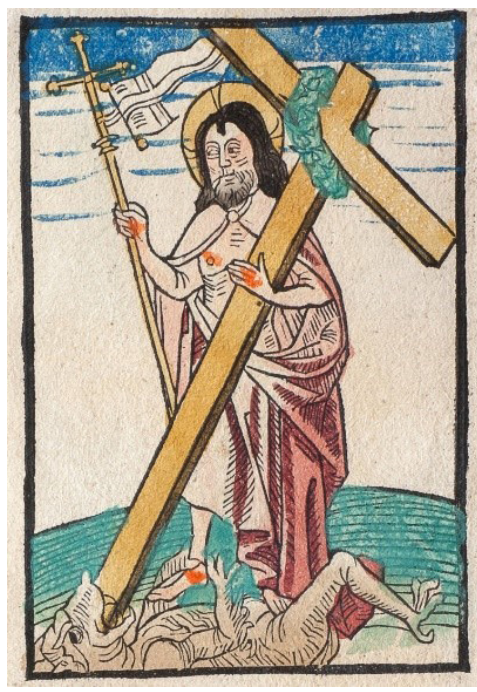

Fig. 5. Cristo venciendo el Príncipe de las tinieblas. Xilografía policromada. Speculum Humanae Salvationis. Basilea, 1476. Biblioteca del Estado de Württemberg, Stuttgart.

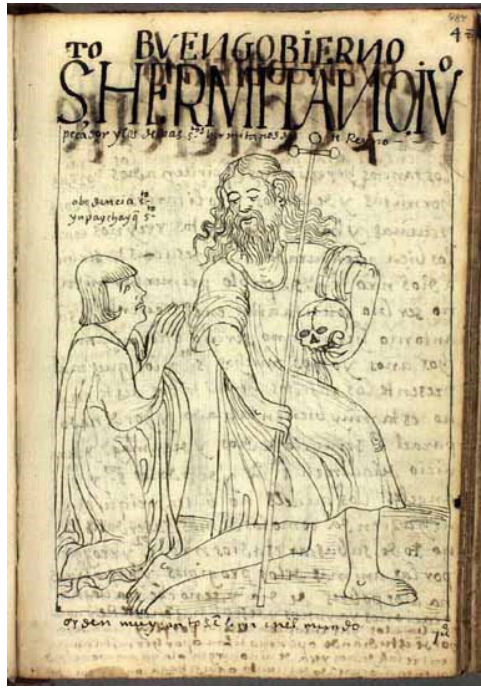

Fig. 6. Felipe Guaman Poma de Ayala, Buen Gobierno /Santo Hermitaño Juan Pecador. Dibujo con pluma y tinta. Nueva corónica y Buen Gobierno. c. 1615-1616. Biblioteca Real, Copenhague. 
Fig. 7. Adam y Eva expulsados del Paraiso y Adam y Eva trabajando. Xilografías policromadas. Speculum Humanae Salvationis. Basilea, 1476. Biblioteca del Estado de Württemberg, Stuttgart.

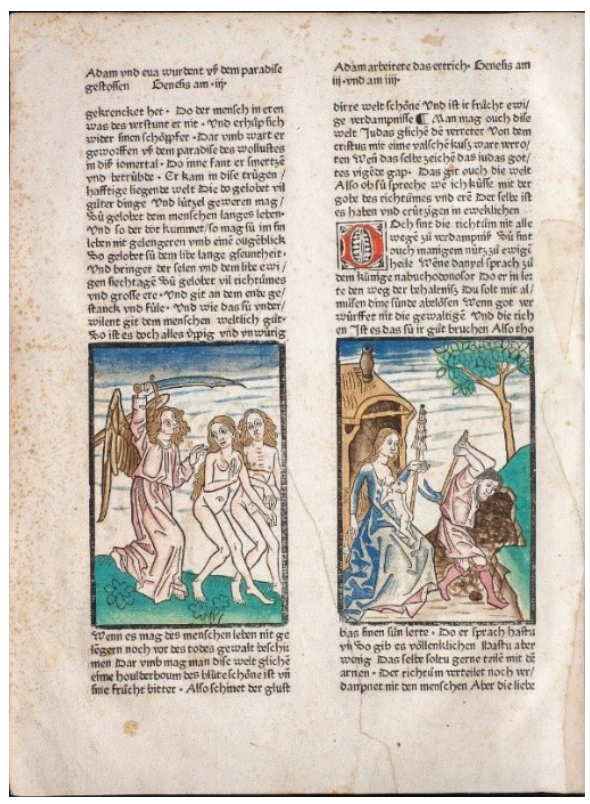

Fig. 8. Asunción. Calcografía. Misal, 1596. Archivo Arzobispal de Ayacucho. Fotografía de la autora.

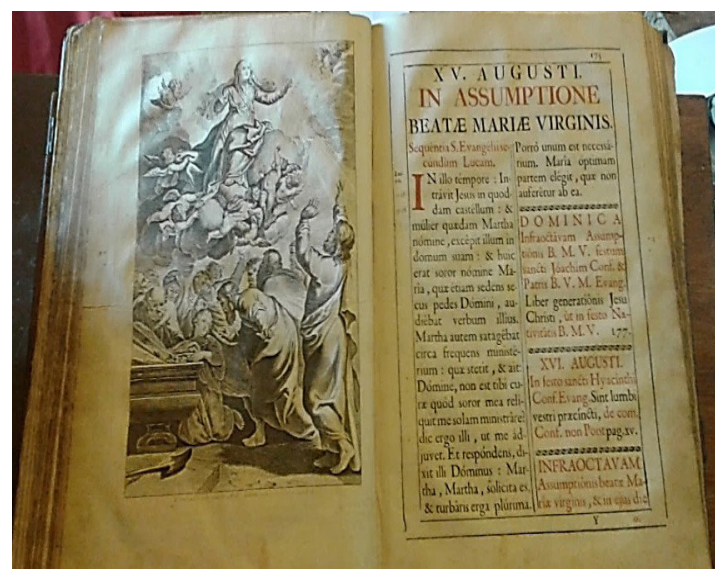




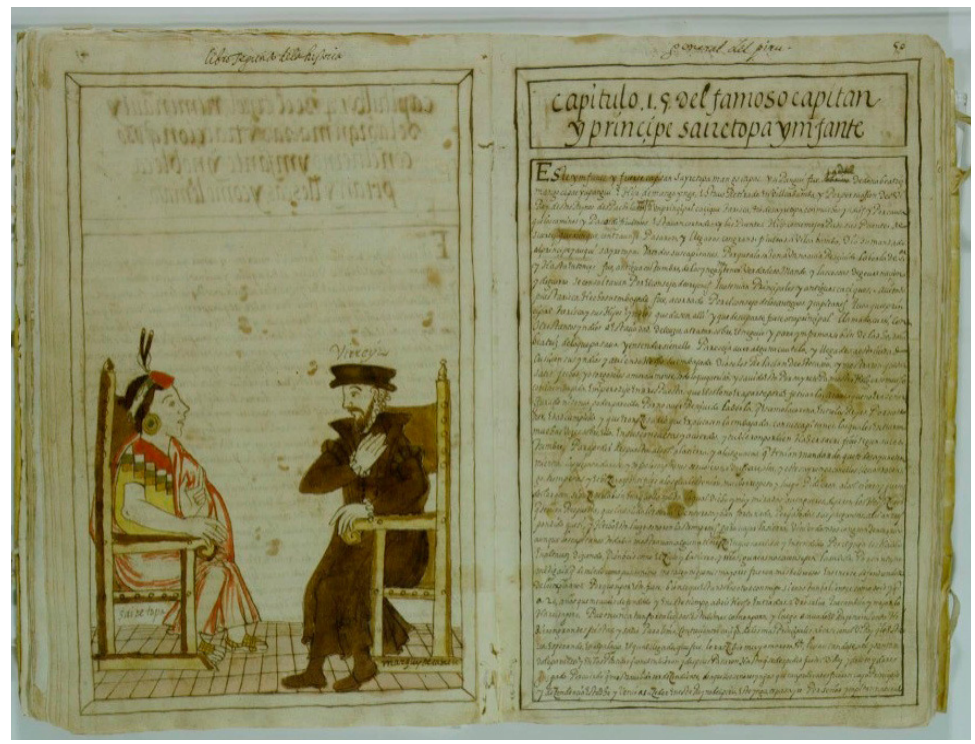

Fig. 9. Felipe Guaman Poma de Ayala. Saire topa / Virrey marqués de Cañete. Tinta y acuarela. Libro segundo de la historia general del Piru en Historia del origen y genealogía real de los reyes ingas del Piru (Manuscrito Galvin). c. 1596-1600. Private Collection Sean Galvin, Dublin.

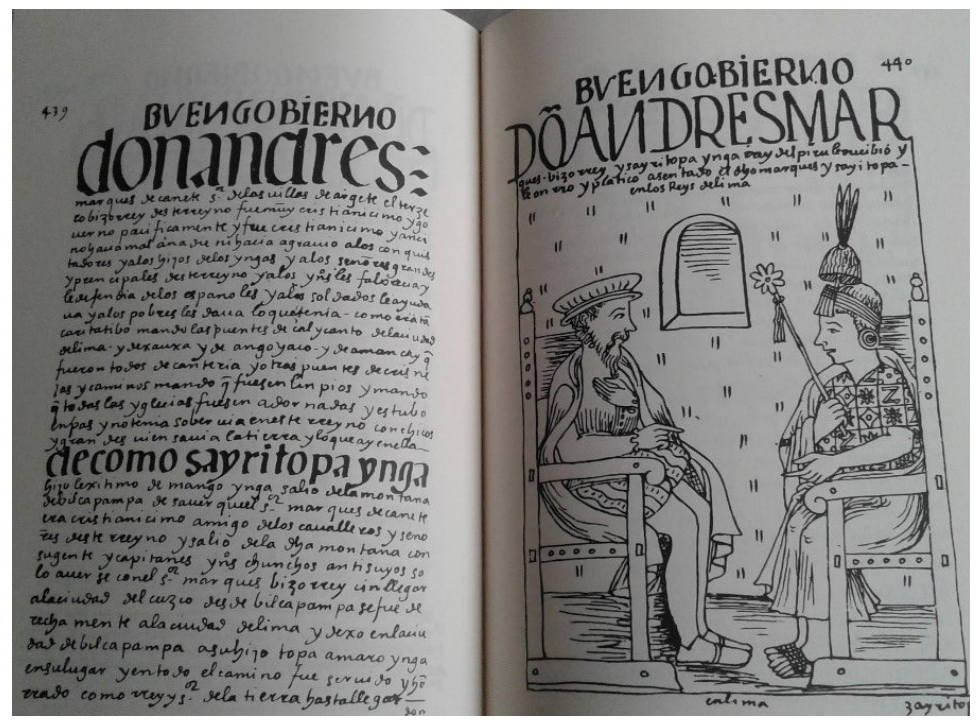

Fig. 10. Felipe Guaman Poma de Ayala, Buen Gobierno / Don Andrés marqués bizorrey y Sayri Topa ynga rrey del Piru le rrecibió y le onrró y platicó asentado el dicho marqués y Sayri Topa I en los Reys de Lima / En Lima. Pluma y tinta. Nueva corónica y Buen Gobierno. c. 1615-1616. Biblioteca Real, Copenhague. 
Guaman Poma mismo, al inicio de su Nueva corónica, usa una fórmula que a primera vista podría parecer un elemento de respuesta:

pase trauajo para sacar con el deseo de presentar a vuestra magestad este dicho libro Yntitulado primer nueua coronica de las yndias del piru y prouechoso a los dichos fieles cristianos escrito y debojado de mi mano y engenio para que la uari[e]dad de ellas y de las pinturas y la enbincion [invención] y dibuxo a que vuestra magestad es enclinado haga fazil aquel peso y molestia de una lectura falta de enbincion y de aquel ornamento y polido ystilo que en los grandes engeniosos se hallan $[\ldots] .^{27}$

Si bien esta cita pareciera ser un punto de partida sugerente a la interrogante que nos preocupa, está casi literalmente copiada de Fray Martín de Murúa quien, como lo muestra Tom Cummins, ${ }^{28}$ usa el mismo texto al inicio de su Manuscrito Galvin. Este texto fue ampliamente conocido por Guaman Poma, ya que gran parte de sus ilustraciones revelan su mano y/o unas muy cercanas. ${ }^{29}$

Además, la fórmula "ornamento y pulido estilo» era un tópico de la literatura del siglo XVI, muy usual especialmente en dedicatorias, de Miguel de Cervantes a Nuñez de Toledo y Guzman. ${ }^{30}$ Por ende, sería un error interpretar dicho párrafo de la Nueva corónica como una expresión altamente personal de Guaman Poma de su voluntad de facilitar y hacer entretenida, a través de los dibujos, la lectura por el monarca español de su obra magna.

Guchte, en su artículo en 1992, se pregunta «de dónde Guaman Poma tuvo la idea para [crear] su Nueva corónica» y si quiso "crear un tipo de manuscrito ilustrado para el rey de España, como era la tradición en la Francia y los Flandes del Medioevo». ${ }^{31}$ También se pregunta si Guaman Poma usó conscientemente diseños anticuados para crear un estilo

\footnotetext{
${ }^{27}$ Guaman Poma de Ayala 1980, I: 7). Lo resaltado es nuestro.

${ }^{28}$ Cummins 2015: 47-48.

${ }^{29}$ Para un estudio de las manos visibles en el Manuscrito Galvin, véase Adorno y Boserup 2008: 12-23 y Velezmoro Montes 2012: 226-257.

${ }^{30}$ Guaman Poma de Ayala 2015, III: 571, nota 73.

${ }^{31}$ Guchte 1992: 94-95.
} 
«a la antigua», como cualquier artista europeo del siglo XVI para quien esto era un paradigma a seguir, nos recuerda el autor, porque otorgaba a la obra una cualidad moral, así como cierta autoridad. Ahora bien, sigue interrogándose Guchte, "¿pero entonces qué significaba 'arte antiguo' para Guaman Poma, el arte precolombino de su Perú natal o los grabados en madera de la Europa del siglo XV?». ${ }^{32}$

Años más tarde, en 2010, Jorge F. Rivas Pérez esboza una respuesta a las interrogantes de Guchte, planteando por un lado que no tiene sentido considerar que Guaman Poma, por ser americano, haya podido querer representar un objeto "all' antigua», y por otro lado, que su afinidad con los grabados tardomedievales puede explicarse por la claridad y simplicidad compositiva de estos, muy acordes con los principios visuales de los ceramios o textiles inca. ${ }^{33}$

Guchte y Rivas Pérez son, de mi conocimiento, los únicos en plantear más específicamente esta interrogante. Aunque Gombrich, quien es tomado por ambos estudiosos como referencia, hace evidente alusión en Norm and Form, con "el estilo all'antica», a otro contexto cultural - es decir, a los artistas renacentistas que tomaban como modelo el arte de la antigüedad grecorromana ${ }^{34}$ — sí creemos que la idea de «all' antica» se puede retomar conceptualmente para Guaman Poma en relación al contexto tardomedieval. ¿Por qué no pensar, en efecto, que la amplia cultura textual de Guaman Poma puede haberlo llevado a este nivel de consciencia histórica, incluyendo cierta conexión entre visualidad e historia? Al menos, la presencia constante de la fecha de edición, en el frontispicio, de los libros, deja pocas dudas sobre el conocimiento que pudo haber tenido el autor indígena del contexto temporal en el cual estos habían sido creados. La pregunta es entonces: ¿quería Guaman Poma que el monarca español, al recibir la Nueva corónica, sintiera que estuviese recibiendo un libro inscrito en la tradición de las décadas y siglos anteriores? ¿Sería algo más respetable para el eminente destinatario?

32 Ib.: 108.

33 Rivas Pérez 2010: 132.

${ }^{34}$ Gombrich 1978: 122-128. 
Los aspectos formales de la Nueva corónica despiertan algunos interrogantes al respecto. Además de su título, que explícitamente indica buscar un carácter novedoso, Guaman Poma desea en buena cuenta realizar una obra moderna. Como Adorno y Cummins lo demostraron, la somete a las normas editoriales de la imprenta, con páginas y no folios, y palabras de llamada debajo de cada página. ${ }^{35}$ Cummins incluso propone la sugerente idea de una ausencia voluntaria de color en los dibujos para que no se rompa la unidad entre texto e imágenes, pero también para elevar el estatus de la obra magna de Guaman Poma, acercándola al aspecto de un libro impreso. ${ }^{36}$

Esta hipótesis nos parece totalmente validada por el solo pedido, al inicio de su obra, del autor andino de mandar al Rey una copia de su manuscrito. ${ }^{37}$ En estas circunstancias, empero, los dibujos de la Nueva corónica manifiestan una tensión implícita: por un lado, buscarían recordar grabados, en la perspectiva de un libro impreso — sinónimo, en el Virreinato del Perú de inicios del siglo XVII, de modernidad-y por otro lado, su visualidad está mucho más cercana a modelos del pasado, en este caso, los tardomedievales, en detrimento de los modernos, a saber, los manieristas.

Es ahí donde creemos que la visualidad de inspiración tardomedieval de Guaman Poma va de la mano con una voluntad de inscribirse también en una tradición del pasado; en este caso, la tradición del género, existente desde la Edad Media, de la crónica. Esta consciencia histórica está comprobada en el acápite de las coronicas pazadas, en el cual Guaman Poma enumera a varios cronistas del siglo XVI. Así, cita como primero de los «sabios historiadores» cronistas de Indias a «Juan Buemo», es decir, el humanista germánico Johann Boemus, canónigo de la catedral de Ulm,

${ }^{35}$ Adorno 1979-1980: 14-18 y 1992: 43; Cummins 1992: 50-51.

${ }^{36}$ Cummins 1992: 55-56.

37 «Prologo al letor [...] y la dicha merced pide y suplica para cienpre de la dicha ynprecion A SV M[AGESTAD] del dicho libro conpuesto por el dicho autor don fe[lipe] guaman poma de ayala señor y capa capo ques principes pues que lo merese de la dicha auilidad y trauajo [...]» (Guaman Poma de Ayala 1980, I: 9). 
viajero y autor de Omnium Gentium Mores, Leges et Ritus, publicado por primera vez en Amberes en 1520, reeditado numerosas veces (entre ellas en Lyon en 1541) y que será de gran popularidad en Europa durante todo el siglo XVI. ${ }^{38}$ Este acápite no solamente cita, sino también critica, positiva o negativamente, a otros autores y cronistas de Indias tales como Agustín de Zárate, Diego Fernández, José de Acosta, Juan Ochoa de la Sale, Jerónimo de Oré, Martín de Murúa, mientras inscribe claramente a la Nueva corónica en esta genealogía de textos.

Guaman Poma, ciertamente, no cita a ninguna crónica medieval, pero no es descabellado pensar que haya podido conocer a algunas, y quizá en primera línea, por la inmensa popularidad de esta obra, la Estoria de España, cuya génesis data del siglo XIII durante la época alfonsí y es bastante compleja, pero que Guaman Poma pudo haber conocido en una edición derivada de los tiempos de la imprenta. ${ }^{39}$ Es importante recordar que las crónicas, desde la Edad Media, cumplían no solamente una función de enseñanza ante los monarcas españoles, a quienes se les leía estos textos, sino que también tenían una dimensión moralizante, en cuanto que el monarca debía de aprender de los errores cometidos en el pasado y enmendarlos. En este sentido, los contenidos denunciadores de la segunda parte de la Nueva corónica, el Buen gobierno, están totalmente acordes con la dimensión moralizante propia de aquellas crónicas.

${ }^{38}$ Guaman Poma parece haberlo conocido gracias a las menciones del cronista oficial de Indias Gonzalo Fernández de Oviedo: «hizo la coronica deste rreyno de las yndias un conbentio [compendio] doctisimo llamado yndiario juan buemo abantiotonio [sic] las hizo comparando los tenples [templos] los ritos y rreys y citios de tierras de todos ellos con los que tienen los yndios naturales deste nuebo orbe segun la cifran breuemente el capitan gonzalo pizarro de obedo y ualdes» (Guaman Poma de Ayala 1980, III: 997); véase también Guaman Poma de Ayala 2015, III: nota 1782.

${ }^{39}$ De la Estoria de España se conservan dos versiones: la "regia» o "primitiva» (h. 1270-1274) y la "crítica» (h. 1282-1284). Véase Menéndez Pidal 1906. La Biblioteca Nacional de España conserva unas veinte ediciones del siglo XIV a XVIII (Biblioteca Nacional de España 2017). 
Además, en este mismo acápite de las coronicas pazadas, a propósito del origen cristiano de los Indios, anterior a la Conquista, que Guaman Poma siempre defendió, se puede leer un pasaje muy sugerente relativo a la voluntad del autor andino de inscribirse en lo que posiblemente se podría llamar aquí una línea de pensamiento histórico-teológico:

Y aci los indios somos cristianos [...] y creemos un solo dios de la sancticima trinidad quiciera oyr y ciguir el pareser de hombres doctos a quien les les $[s i c]$ constara desta conparación como a mí que las e hecho muchas beses más que seguir el propio y dar sentencia tan nueba cómo pareserá a los no bercados en historias la que escribo aora en fabor y seruicio de Dios y de su Magestad y bien de los pobres. ${ }^{40}$

Por otro lado, líneas más abajo, en el contexto de su narración de la historia del mundo, de los indios y de la Conquista, cita llamativamente a soberanos europeos anteriores a su tiempo —al emperador Maximiliano I (1459-1519), al emperador Carlos V (1500-1558) y a la madre de este último, Doña Juana (1479-1555):

Diospa pachan rreyna doña Juana. Enperador Maximiliano cascanmanta, runa chaypa capitánnin don Carlos rrey enperadorpa, cachan enbaxadornin don Francisco Pizarro, don Diego Almagro cascanmanta, runa enperadorpa cachan oydores pricidentes birrey Blasco Nuñes de Uela, birrey don Antonio de Guzmán, birrey don Andrés, marqués cascanmanta runa rrey don Felipe segundo paypa cachan don Francisco de Toledo bizorrey. ${ }^{41}$

Sin que sea necesario cuestionar la visión sincrética del tiempo claramente identificada en la Nueva corónica, en una fusión, nuevamente ahí en parte consciente, entre relatos de carácter histórico-europeo y otros de índole mítico-prehispánico, ${ }^{42}$ la dimensión no solamente enunciativa, sino también crítica del acápite de las coronicas pazadas nos parece constituir una referencia valiosa, además de todo lo desarrollado

${ }^{40}$ Guaman Poma de Ayala 1980, III: 998. Lo resaltado es nuestro.

41 Ib.: 998-999.

42 Entre los primeros estudios sobre el tema, véase en prioridad Wachtel 1971 y Ossio 1973. Ossio propone que "Guaman Poma se mueve bajo dos sistemas de conceptualización del tiempo distintas que trata de reconciliar» (1973: 195). 
en las líneas anteriores, para proponer la existencia de una consciencia histórica en Guaman Poma. De todo ello, se desprende la posibilidad de leer la visualidad de inspiración tardomedieval de la Nueva corónica como una intención de enmarcarse en una tradición del pasado y así reforzar el peso histórico de su obra.

Entonces, la Nueva corónica y buen gobierno es una obra que aspiraba a ser nueva no solo por sus contenidos, así como por ciertos aspectos formales más acordes con su tiempo; sino también, por su inscripción consciente en la historia del género literario de la crónica. Por otro lado, como hemos visto, debido a su visualidad, es a su vez un libro enmarcado en fuentes escritas y visuales del pasado. Esta tensión entre lo moderno y lo antiguo puede resultar hasta hoy perturbadora — sobre todo si le añadimos a esto su concepción también andina del tiempo- pero lo más probable es que Guaman Poma, más bien, consideraría la fusión de ambas dimensiones, la antigua y la moderna, como una manera de sintonizar plenamente con la cultura literaria y visual del monarca español, al cual su obra magna estaba destinada, y volverla así más respetable a sus ojos.

IMPRONTA VISUAL PREHISPÁNICA: AFINIDADES CON LO TARDOMEDIEVAL, USOS Y ABANDONOS

Llegamos ahora, justamente, al segundo eje de reflexión inherente a la idea de intención estilística en Guaman Poma: su evidente cercanía con ciertos rasgos de la visualidad prehispánica, especialmente la inca. Respecto a esta relación, queremos abordar dos aspectos: por un lado, las afinidades visuales que posiblemente encontró el artista andino entre los grabados tardomedievales y su imaginario artístico de tradición prehispánica; y por otro lado, el — parcial, pero sugerente- abandono de ciertas composiciones de clara impronta visual inca, visibles en el Manuscrito Galvin pero luego ausentes en la Nueva corónica.

Wachtel, Ossio, Adorno y López-Baralt fueron los primeros en explorar, desde una perspectiva histórica, antropológica o semiótica, la hipótesis de la inclusión de una concepción andina del espacio en las imágenes 
de Guaman Poma sobre, entre otros, la base conceptual de la dualidad Hanan/Hurin. ${ }^{43}$ Gisbert y Cummins, por su lado, establecieron interesantes relaciones entre Guaman Poma y los qeros, mostrando cómo, por ejemplo, los retratos frontales de los Incas al inicio de la Nueva corónica constituyen una suerte de eslabón faltante entre las conocidas representaciones de qeros inca y las coloniales más tardías. ${ }^{44}$

Mi principal propósito aquí es confrontar qeros inca con varias acuarelas de la Historia del origen y genealogía real de los reyes ingas del Piru. Juan Ossio, en su estudio del manuscrito que halló, bautizó como Manuscrito Galvin y publicó en 2004 como fac simile, hace referencia de manera muy breve a ciertas similitudes visuales entre qeros y algunas escenas del Manuscrito Galvin, y publica una pareja de imágenes a modo de ilustración. ${ }^{45}$

De facto, no cabe la menor duda que los motivos presentes en los vasos sagrados hayan marcado la concepción del espacio, y de la forma en general, de Guaman Poma, especialmente el Guaman Poma más temprano del Manuscrito Galvin: así lo demuestran su gusto por dejar espacios enteramente vacíos (hasta la mitad de la altura de la composición en unos casos), el uso recurrente de formas geométricas — como el triángulo, el rombo o el rectángulo-, la división del espacio en niveles separados, y, en general, la linealidad decidida de estas composiciones, todas características formales que les otorgan a estas acuarelas una sorprendente pureza geométrica (figs. 11-16).

${ }^{43}$ Wachtel 1971: 79; Wachtel 1973: 165; Ossio 1973; Adorno 1979a y 1979b; Adorno 1986: 80; Adorno 1989, I: 118; López-Baralt 1988: 202.

${ }^{44}$ Gisbert compara un kero con la imagen frontal de un Inca con el dibujo de Guaman Poma representando el Inca Manco Capac (Guaman Poma de Ayala 1980, I: 67). Además, cita a Cummins en relación a la importancia de los dibujos de Guaman Poma para cubrir ciertos vacíos de la historia en cuanto a la historia visual de los qeros: «Cummins states that 'Guaman Poma's work is therefore important to the study of seventeenthand eighteenth-century kero imagery because it bridges the gap between the inicial icononoclastic campaign of the 1570's and the production of pictorial kero imagery in the seventeenth century. Guaman Poma's images demostrate the kind of change that occurred in native artistic expression» (Gisbert 1992: 82).

${ }^{45}$ Ossio 2004, 28: fig. 4) 


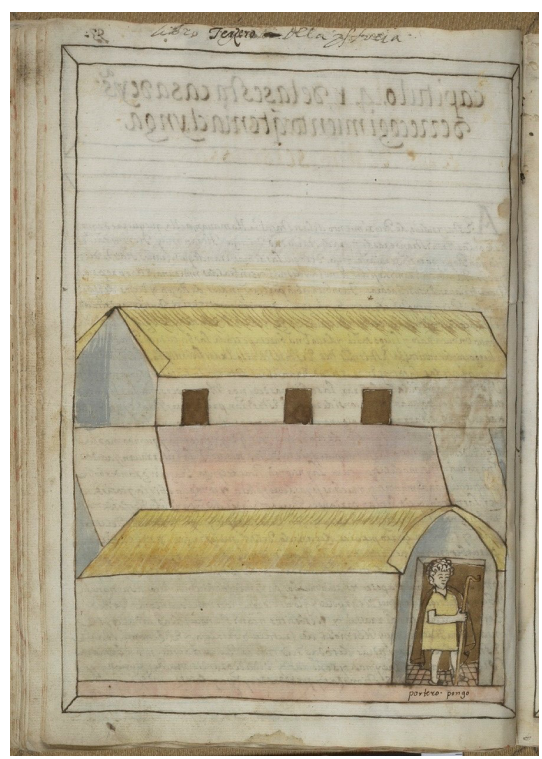

Fig. 11. Felipe Guaman Poma de Ayala, Portero, tinta y acuarela, en Libro tercero de la historia general del Piru en Historia del origen y genealogía real de los reyes ingas del Piru. c. 1596-1600. Private Collection Sean Galvin, Dublin.

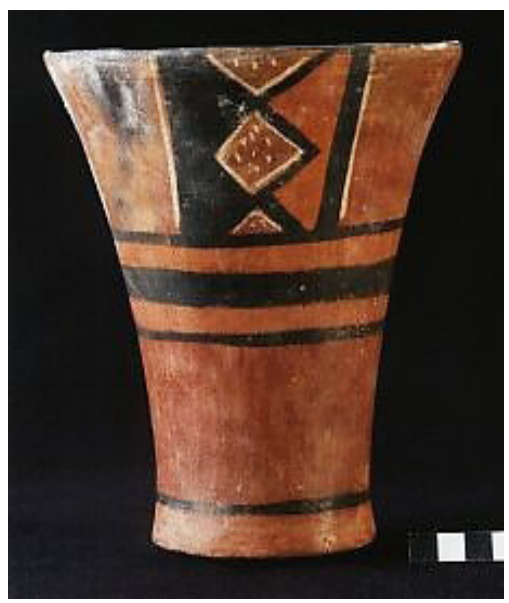

Fig. 12. Qero. Cerámica policromada. Época imperial Inca (1300-1532). Colección privada Eduardo Jiménez C., Puerto de Ilo, Perú. 
Fig. 13. Qero. Madera. Época imperial Inca (1300-1532). Museo Arqueológico Rafael Larco Herrera, Lima.

Fig. 14. Felipe Guaman Poma de Ayala, Dos casas de piedra parda de cantería del Inga, tinta y acuarela, en Libro tercero del Govierno del Piru en Historia del origen y genealogía real de los reyes ingas del Pirú. Private Collection Sean Galvin, Dublin.
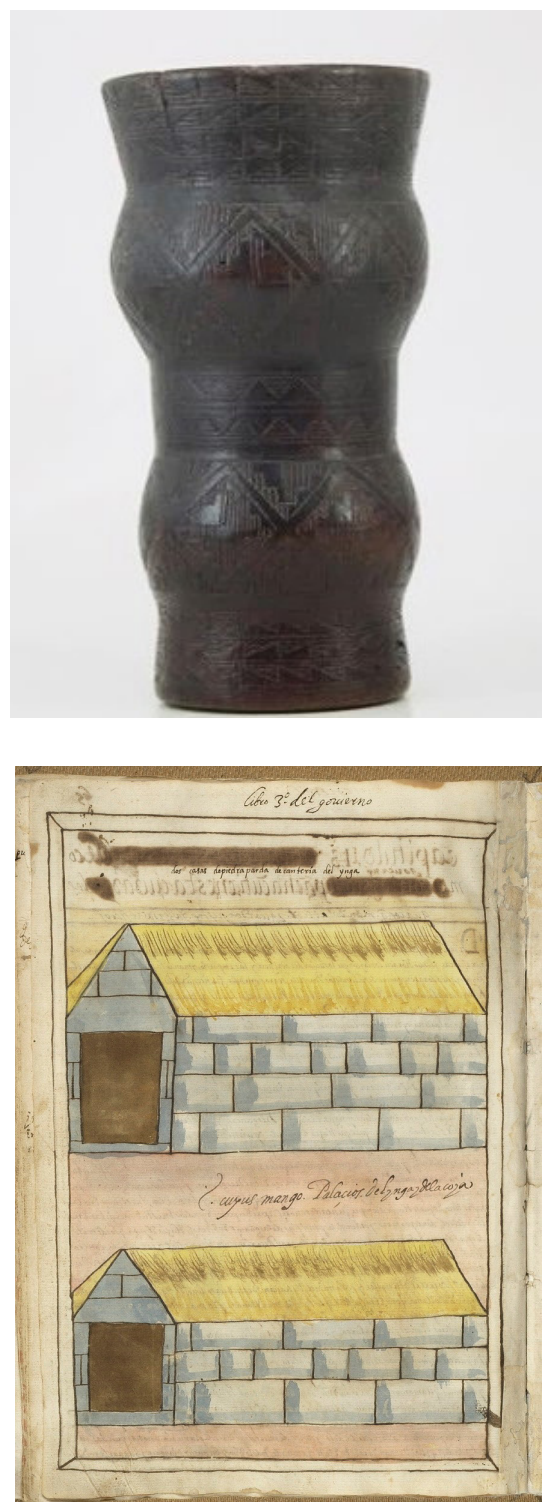


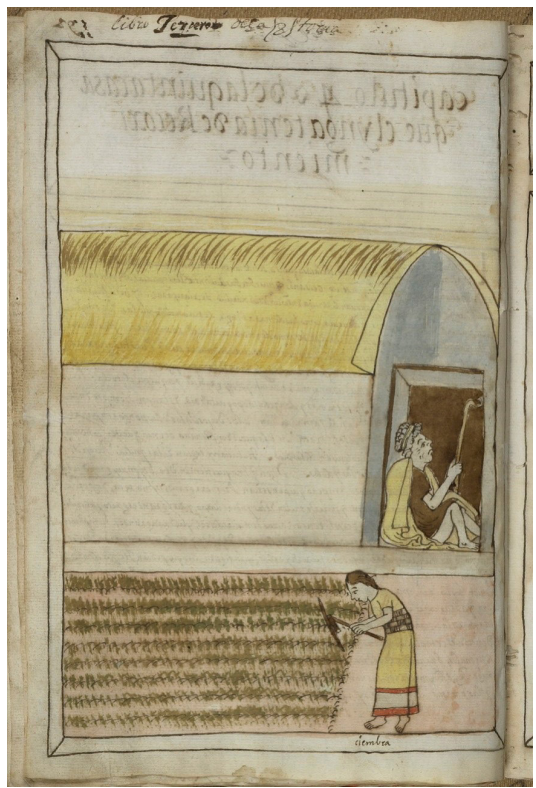

Fig. 15. Felipe Guaman Poma de Ayala, Ciembra. Tinta y acuarela. Libro tercero de la historia del Piru en Historia del origen y genealogía real de los reyes ingas del Piru. Private Collection Sean Galvin, Dublin.

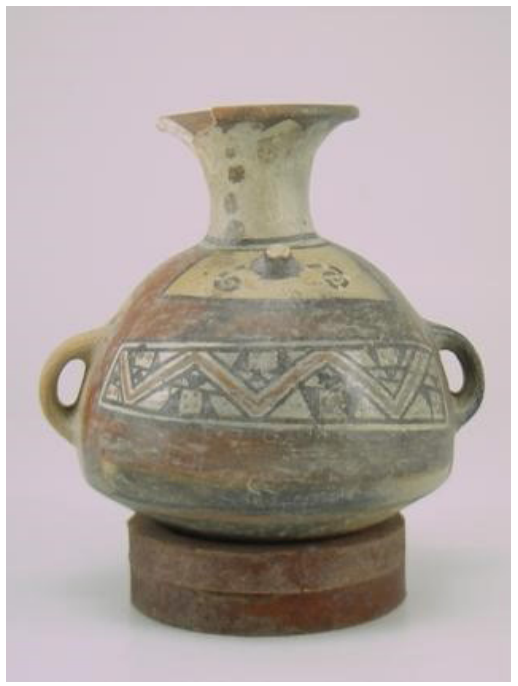

Fig. 16. Cántaro, cerámica. Época imperial Inca (1300-1532). Museo Arqueológico Rafael Larco Herrera, Lima. 
A la luz de estas comparaciones, sí nos parece entonces bastante plausible (como a Rivas Pérez) que si Guaman Poma tuvo acceso, como casi no caben dudas, a ilustraciones grabadas de libros tardomedievales, entonces haya acogido con relativa naturalidad estos modelos por ser más acordes con su propia tradición andina: los grabados que ornaban los incunables y los libros impresos entre los ańos 1520 y 1530 eran, pues, de composiciones espacialmente mucho más legibles y de perspectivas más planas que los grabados manieristas presentes en las publicaciones más tardías del siglo $\mathrm{XVI}$, regidos por la sofisticación de los detalles y la profusión decorativa. En este sentido, al confrontar nuevamente en una secuencia de imágenes, lo tardomedieval, lo pomaniano y lo manierista (figs. 17-19), se podrá corroborar en la visualidad pomaniana, a su vez marcada por herencias prehispánicas, una mayor cercanía con lo tardomedieval que con lo manierista.

Además de las probables afinidades entre tradición visual andina y grabados tardomedievales, cabe resaltar que el Manuscrito Galvin ostenta, en conjunto, una visualidad más evidentemente andina y prehispánica que la Nueva corónica por la presencia recurrente de composiciones geométricas, lineales, divididas en niveles, y que no pocas veces dejan bastante espacio vacío, como en muchos qeros incas. La relación entre visualidad y hechos históricos se hace entonces más patente, pues además de ser anterior a la Nueva corónica, el Manuscrito Galvin precisamente cuenta exclusivamente la historia de los Incas. En este sentido, nos parece pertinente pensar en una correlación entre la visualidad tardomedieval del autor indígena y su conexión con la tradición andina prehispánica, pero no solamente por una comodidad técnica o un gusto estético, sino también en el contexto de un proceso de cambio y de adaptación entre el estilo pomaniano del Manuscrito Galvin y el de la Nueva corónica.

Lo interesante de aquellas escenas del Manuscrito Galvin, que se ilustran por composiciones extremadamente lineales, depuradas y geométricas es que ya no vuelven a aparecer en la Nueva corónica, a diferencia de muchas otras composiciones que serán retomadas, de manera cuasi o parcialmente idéntica. Existe entonces una serie de imágenes que ya no se pueden observar en la obra magna de Guaman Poma, y que representan por lo tanto un unicum en su producción artística. 


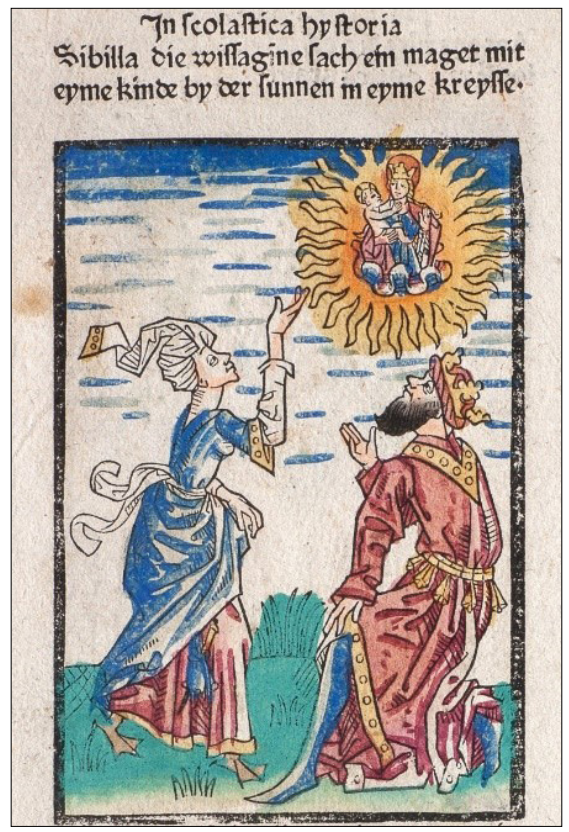

Fig. 17. Sibila de Jerusalén. Xilografía policromada. Speculum Humanae Salvationis, Basilea, 1476. Biblioteca del Estado de Württemberg, Stuttgart.

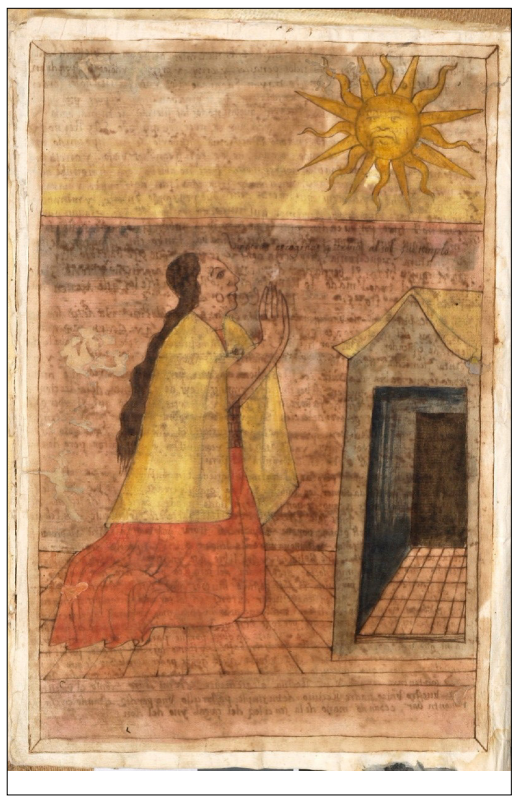

Fig. 18. Felipe Guaman Poma de Ayala, Virgenes escogidas [...] al sol y al templo, tinta y acuarela, en Libro primero de la Historia del origen y genealogía real de los reyes ingas del Piru. Private Collection Sean Galvin, Dublin.

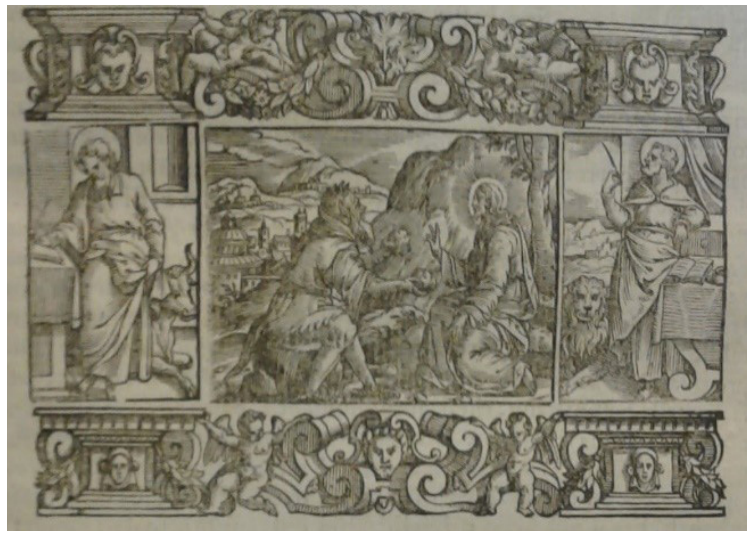

Fig. 19. Jesús tentado por el diablo. Calcografía. Libro de Sermones y Epistolas de San Pablo. Venecia, 1587, Archivo Arzobispal de Ayacucho. Fotografía de la autora. 
Este abandono se debe muy probablemente a la preocupación del artista andino por ofrecer a su eminente destinatario europeo unas escenas estéticamente más familiares a su ojo. De ahí el uso más intensivo de modelos europeos para sus dibujos. Para nosotros, este fenómeno es una prueba más de una intención estilística en Guaman Poma; es decir, cierto pragmatismo a la hora de reutilizar, para la Nueva corónica, composiciones que se pueden observar en el Manuscrito Galvin, pero también, para la mayoría de los casos, una gran capacidad de innovación, totalmente orientada a su propósito principal: llamar la atención del monarca español a través de escenas que dejan cada vez más lugar a una visualidad europeizante. Incluso, en algunos casos — como la escena del encuentro en 1560 entre el Inca Sayri Topa y el marqués de Cañete Don Andrés Hurtado de Mendoza—, el mismo evento está representado en ambos manuscritos, pero la distribución y en general la evocación del espacio son más claramente inspiradas en la Nueva corónica por patrones compositivos europeos, como es la supresión del espacio vacío en la mitad superior de la imagen, o la integración de una ventana (figs. 9-10).

Regresemos un instante, para terminar, a la segunda interrogante de Guchte: «¿Pero entonces qué significaba 'arte antiguo' para Guaman Poma? El arte precolombino de su Perú natal o los grabados en madera de la Europa del siglo XV?».46 Si bien nos parece poco probable que Guaman Poma haya razonado en estos términos, sí nos parece que la clara selección de formas operada por él y la evolución de estas en el tiempo, son evidencias de un artista que estuvo adquiriendo una consciencia del arte del pasado y del presente, así como del discurso intrínseco que las formas en sí pudieran tener, además y más allá de la representación.

\section{A MODO DE CONCLUSIÓN}

Al considerar la existencia de una consciencia artística, y más específicamente de una intención estilística en Guaman Poma, se ha podido leer bajo un nuevo enfoque su relación con los grabados tardomedievales y con ciertos rasgos compositivos de tradición prehispánica, especialmente

${ }^{46}$ Véase nota 30. 
incaica. La visualidad de inspiración tardomedieval de sus dibujos, en realidad ya presente en muchas composiciones del Manuscrito Galvin y probablemente debida a ciertas afinidades naturales con patrones compositivos andinos, nos parece adquirir una dimensión particular en el contexto de la Nueva corónica, destinada a Felipe III: adicionalmente al claro posicionamiento del autor en una tradición literaria, la inspiración tardomedieval de los dibujos, muy alejada del arte contemporáneo manierista, permite a Guaman Poma mostrarse, también a través de la imagen, como un autor inscrito en una determinada tradición visual, otorgando así a su carta al rey un mayor peso histórico. Por otro lado, el uso de ciertos rasgos compositivos andinos, llevados a su máxima expresión en algunas páginas del Manuscrito Galvin, y que en la Nueva corónica serían parcialmente abandonados, revela a un artista plenamente consciente de los retos que se plantea y de las herramientas que necesita para cumplirlos: en este caso, hacer que las escenas representadas en su obra magna sean las más afines posibles con la cultura visual de su destinatario. Así, por la evidente selección de formas a la cual procede y al mismo tiempo por su gran capacidad de invención, Guaman Poma se revela como un verdadero auctor, que supo trascender el proceso mismo de apropiación formal, encontrando, con su correspondiente evolución intrínseca, un lenguaje visual a la medida de sus ambiciones históricas y políticas.

\section{BIBLIOGRAFÍA}

Adorno, Rolena. 1974. «Racial Scorn and Critical Contempt». Diacritics. Vol. 4, Núm. 4: 2-7.

. 1978. «Las otras fuentes de Guaman Poma: sus lecturas castellanas». Histórica. Vol. 2, Núm. 2: 137-158.

. 1979a. «Icon and idea: A symbolic Reading of the Visual Text of Guaman Poma». The Indian Historian. Vol. 12, Núm. 3: 27-50.

. 1979b. «Paradigms Lost: A Peruvian Indian Surveys Spanish Colonial Society». Studies in the Anthropology of Visual Communications. Núm. 5: 78-96. . 1979-1980. "The New Chronicle and Good Government: A New Look at the Royal Library's Peruvian Treasure». Fund og Forskning. Núm. 24: 7-28. 
. 1984. «Paradigmas perdidos: Guamán Poma examina la sociedad española colonial». Revista Chungará. Núm. 13: 67-91.

1986. Guaman Poma: Writing and Resistance in Colonial Peru. Austin: Universidad de Texas.

. 1991. Guaman Poma. Literatura de resistencia en el Perú. México D.F.: Siglo Veintiuno Editores.

. 1992. «Don Felipe Guaman Poma de Ayala: Author and Prince». En Adorno, Rolena, Cummins, Tom et al. 1992. Guaman Poma de Ayala. The Colonial Art of an Andean Author. New York: Americas Society, 32-45.

. 1993. «The Genesis of Felipe Guaman Poma de Ayala's Nueva corónica y buen gobierno». Colonial Latin American Review. Núm. 2: 53-91.

, Tom Cummins et al. 1992. Guaman Poma de Ayala. The Colonial Art of an Andean Author. New York: Americas Society.

. 1995. «La génesis de la Nueva Corónica y Buen Gobierno de Felipe Guaman Poma de Ayala». Taller de Letras. Revista del Instituto de Letras de la Pontificia Universidad Católica de Chile. Núm. 23: 9-45.

Adorno, Rolena e Ivan Boserup. 2005. "Guaman Poma and the Manuscripts of Fray Martín de Murúa: prolegomena to a critical edition of the Historia del Peru». Fund og Forskning i Det Kongelige Biblioteks Samlinger. Núm. 44: 107-258. . 2008. «The Making of Murúa's Historia General del Piru». En Cummins, Thomas B. F. y Barbara Anderson (eds.). The Getty Murúa. Essays on the Making of Martín de Murúa's Historia General del Pirú. Los Angeles: Getty Research Institute: 7-47.

. 2013. «Felipe Guaman Poma de Ayala: Native Writer and Litigant in Early Colonial Peru». En Andrien, Kenneth J. (ed.). The Human Tradition in Colonial Latin America. Londres: Rowman \& Littlefield, 173-198.

. 2015. Unlocking the Doors to the Worlds of Guaman Poma y His Nueva corónica. Copenhague: Museum Tusculanum Press.

Albó, Xavier. 1998. «La Nueva corónica y buen gobierno: ¿obra de Guaman Poma de Ayala o de jesuitas?». Anthropologica. Especial: Polémica sobre Guaman Poma de Ayala. Núm. 16: 307-348.

Anunciación, Fray Domingo de la. 1565. Doctrina Cristiana breve. México: Pedro Ocharte.

Barnes, Monica. 1995. «Las edades del hombre y del mundo según Hierónimo Chaves, de Sevilla y Guaman Poma de Ayala, del Perú». En Schobinger, Juan (comp.). Humanismo siglo XX: Estudios dedicados al Dr. Juan Adolfo Vázquez. San Juan: Editorial de la Universidad Nacional de San Juan, 291-297.

Biblioteca Nacional de España. 2017. El hallazgo del pasado. Alfonso El Sabio y la Estoria de España, 31 de enero - 16 de abril de 2017, Sala Mínima, Museo de la Biblioteca Nacional de Espańa, Madrid. 
Cabos Fontana, Marie-Claude. 2000. Mémoire et acculturation dans les Andes. Guaman Poma de Ayala et les influences européennes. París: L'Harmattan.

Chevalier, François. 1944. «El códice ilustrado de Poma de Ayala». Revista de Indias. Vol. V, Núm. 17: 525-534.

Cummins, Thomas B.F. 1988. Abstraction to Narration: Kero Imagery of Peru and the Colonial Alteration of Native Identity. Tesis de doctorado. Los Ángeles: University of California.

. 1992. "The Uncomfortable Image: Pictures and Worlds in the Nueva corónica i buen gobierno». En Adorno, Rolena, Tom Cummins et al. Guaman Poma de Ayala. The Colonial Art of an Andean Author. New York: Americas Society, 46-59.

. 2008. «The Images in Murúa's Historia General del Pirú: An Art Historical Study». En Cummins, Thomas B. F. y Barbara Anderson (eds.), The Getty Murua. Essays on the Making of Martin de Murúa's Historia General del Pirú. Los Angeles: Getty Research Institute, 147-173.

. 2015. «El mundo y vida de las imágenes en las páginas peruanas de los siglos XVI y XVII: el contexto virreinal de las obras de Martín de Murúa, Guamán Poma y otros». En Michaud, Cécile (ed.). Escritura e imagen en Hispanoamérica. De la crónica ilustrada al comic. Lima: Fondo Editorial PUCP, 21-64.

Cummins, Thomas B. F.; Engel, Emily; Anderson, Bárbara y Juan Ossio (eds.). 2014. Manuscript Cultures of Colonial Mexico and Peru. New Questions and Approaches. Los Angeles: Getty Research Institute.

Eguiguren, Luis Antonio [Multatuli]. 1945. «El fundador de la imprenta en Lima». En Multatuli. Las calles de Lima. Lima, 333-368.

Fleming, David. 1994. "Guaman Poma, Hieronymo de Chaues and the Kings of Persia». Latin American Indian Literatures Journal. Vol. 10, Núm. 1: 46-60. Freedberg, Sydney Joseph. 1978. Painting in Italy, 1500-1600. Yale: Yale University Press.

Fritz, Sabine. 2009. Hybride andine Stimmen. Die narrative Inszenierung kultureller Erinnerung in kolonialzeitlichen Chroniken der Eroberten. Hildesheim /Zürich / New York: Georg Olms Verlag.

García Aguilar, Idalia y Pedro Rueda Ramírez (coords.). 2014. El libro en circulación en la América colonial. Producción, circuitos de distribución y conformación de bibliotecas en los siglos XVI al XVIII. México: Ediciones Quivira.

Gisbert, Teresa. 1992. "The Artistic World of Felipe Guaman Poma de Ayala». En Adorno, Rolena, Tom Cummins et al. Guaman Poma de Ayala. The Colonial Art of an Andean Author. New York: Americas Society, 75-91.

Gombrich, Ernst. 1978. Norm and Form. Studies in the Art of Renaissance I. Londres: Phaidon Press. 2009. «Style». En Preziosi, Daniel. The Art of Art History, Oxford: Oxford University Press, 129-140. 
González Díaz, Soledad. 2012. «Guaman Poma y el Repertorio anónimo (1554): una nueva fuente para las edades del mundo en la Nueva corónica y buen gobierno». Chungara, Revista de Antropología Chilena. Vol. 44, Núm. 3: 377-388.

Grañen Porrúa, María Isabel. 2011. Los grabados en la obra de Juan Pablos. Primer impresor de la Nueva España 1539-1560. México: Fondo de Cultura Económica. Griffin, Clive. 1989. The Crombergers of Seville: The History of a Printing and Merchant Dynasty. Oxford: Oxford University Press.

Guaman Poma de Ayala, Felipe. 1980. El primer Nueva Corónica y buen gobierno [1615-16]. Edición a cargo de John V. Murra y Rolena Adorno; traducciones del quechua por Jorge L. Urioste. México: Siglo Veintiuno Editores.

. 1993. Nueva Corónica y buen gobierno [1615-16]. Edición y prólogo a cargo de Franklin Pease; Vocabulario y traducción a cargo de Jan Szemiński. Lima: Fondo de Cultura Económica.

2001. El sitio de Guaman Poma. Copenhague: Biblioteca Real de Dinamarca. Recurso en línea. Edición facsimilar digitalizada. http://www.kb.dk/ permalink/2006/poma/info/es/foreword.htm .2015. Nueva Crónica y buen gobierno. Lima: Biblioteca Nacional del Perú. . 2017. Nueva Crónica y buen gobierno. Colección Bicentenario. Ed. de Carlos Araníbar. Lima: Biblioteca Nacional del Perú/ Ministerio de Relaciones Exteriores. Guchte, Maarten van de. 1992. «Invention and Assimilation: European Engravings as Models for the Drawings of Felipe Guaman Poma de Ayala». En Adorno, Rolena, Tom Cummins et al. Guaman Poma de Ayala. The Colonial Art of an Andean Author. New York: Americas Society, 92-109.

Guibovich, Pedro. 1991. «Cristóbal de Albornoz y el Taqi Onkoy». Histórica. Vol. XV, Núm. 2: 205-236.

. 2014. «Autores, censores y producción de libros en el virreinato peruano». En García Aguilar, Idalia y Pedro Rueda Ramírez (coords.). El libro en circulación en la América colonial. Producción, circuitos de distribución y conformación de bibliotecas en los siglos XVI al XVIII. México: Ediciones Quivira, 95-111.

. 2017. «Indios y libros en el virreinato del Perú». En Cabanillas Cárdenas, Carlos F. (ed.). Sujetos coloniales: escritura, identidad y negociación en Hispanoamérica, siglos XVI-XVIII, New York: IDEA/IGAS, 171-193.

Hampe, Teodoro. 1996. Bibliotecas privadas en el mundo colonial: la difusión de libros e ideas e el virreinato del Perú (siglos XVI-XVII). Frankfurt: Vervouet Verlag. Holland, Augusta E. 2008. Nueva Coronica. Tradiciones artísticas europeas en el Virreinato del Perú, Cusco: Centro Bartolomé de las Casas.

Leonard, Irving A. 2004. Los libros del conquistador. Traducción de Mario Monteforte Toledo, Gonzalo Celorio Morayta y Martí Soler. México: Fondo de Cultura Económica.

Levi-Strauss, Claude. 1985. La vía de las máscaras. Traducción de Juan Almela. México/Madrid/Bogotá: Siglo Veintiuno Editores. 
López-Baralt, Mercedes. 1988. Icono y conquista: Guaman Poma de Ayala. Madrid: Hiperion.

Martínez Sagredo, Paula. 2011. «Algunas reflexiones sobre las prácticas escriturarias en los Andes coloniales (siglo XVII)». Atenea. Núm. 503: 93-109. https://doi. org/10.4067/s0718-04622011000100005

Menéndez Pidal, Ramón (ed.). 1906. Primera Crónica General. Estoria de España que mandó a componer Alfonso el Sabio y se continuaba bajo Sancho IV en 1289. Madrid: Bailly-Baillière e Hijos Editores. https://archive.org/stream/ primeracrnicage 01 sancgoog\#page/n8/mode/2up

Mesa, José de y Teresa Gisbert. 1974. Bitti, un pintor manierista en Sudamérica, La Paz: Universidad Mayor de San Andrés.

. 1982. Historia de la pintura cuzqueña. Lima: Fundación Wiese. . 1983. «El Hermano Bernando Bitti - Escultor». En Torres Ramírez, Bibliano y Hernández Palomo, José (eds.). Actas II Jornadas de Andalucía y América. Sevilla: Escuela de Estudios Hispano-Americanos, 411-427.

Murúa, Fray Martín de. 2004. Historia y genealogía de los reyes ingas del Piru. Códice Murúa. Manuscrito Galvin. Edición facsimilar. Madrid: Testimonio Compañía Editorial.

Oré, Fray Luis Jerónimo de. 1598. Symbolo Cathólico Indiano. Lima: Antonio Ricardo.

Ossio, Juan. 1973. «Guaman Poma: Nueva Corónica o Carta al rey. Un intento de aproximación a las categorías del pensamiento del mundo andino». En Ossio, Juan (ed.). Ideología mesiánica del mundo andino. Lima: Edición Ignacio Prado Pastor, 153-215.

. 1998. «El original del manuscrito Loyola de Fray Martín de Murúa».

Colonial Latin American Review. Vol. VII, Núm. 2: 271-278.

. 2008. En búsqueda del orden perdido. La idea de la historia en Felipe

Guaman Poma de Ayala. Lima: Pontificia Universidad Católica del Perú.

Pease, G. Y., Franklin. 1989. «Felipe Guaman Poma de Ayala. Mitos andinos e Historia Occidental». Historia y Cultura. Núm. 13-14: 155-170. 2010. Las crónicas y los Andes. Lima: Fondo de Cultura Económica del Perú.

Pietschmann, Richard. 1968. "Renseignements sommaires». En Rivet, Paul (ed.). Nueva Corónica y Buen Gobierno. Codex péruvien illustré. París: Institut d'Ethnologie.

Plas, Sophie. 1996. «Une source européenne de la Nueva Coronica y buen govierno de Guaman Poma». Journal de la Société des Américanistes. Vol. 82, Núm. 1: 97-116. Rivas Pérez, Jorge F. 2010. «Mediterranean Material Culture in the Andes: Spanish Furniture in Guaman Poma de Ayala's El Primer Nueva Coronica y Buen Gobierno». En Pierce, Donna (ed.). The Arts of South America 1492-1850. Papers from the 2008 Mayer Center Symposium at the Denver Museum. Denver: Denver Museum, 119-140. 
Speculum Humanae Salvationis. 1476. Basilea: Bernhard Richel. Inc. Fol. 14936, Biblioteca del Estado de Württemberg, Stuttgart.

Stastny, Francisco. 1980. «Maniera o contramaniera». En La dispersión del manierismo. México: Universidad Nacional Autónoma de México / Instituto de Investigaciones Estéticas: 197-230.

Velezmoro Montes, Víctor. 2012. Estudio de los dibujos atribuidos al cronista y dibujante Felipe Guaman Poma de Ayala. (Perú, ss. XVI-XVII). Un análisis estilistico. Tesis de doctorado. Sevilla: Universidad de Sevilla.

Wachtel, Nathan. 1971. «Pensée sauvage et acculturation: L'espace et le temps chez Felipe Guaman Poma de Ayala et l'Inca Garcilaso de la Vega». Annales. Histoire, Sciences Sociales. Vol. 26, Núm. 3/4: 793-840.

. 1973. Sociedad e ideología: Ensayos de historia y antropología andinas. Lima: Instituto de Estudios Peruanos.

Zemon Davis, Natalie. 1983. «Beyond the Market: Books as Gifts in SixteenthCentury France: The Prothero Lecture». Londres: Royal Historical. Vol. 33: 69-88. https://doi.org/10.2307/3678990

Zumarraga, Fray Juan de. 1547. Regla christiana breve. México: Juan Pablos.

Fecha de recepción: 3/III/2018

Fecha de aceptación: 16/V/2018 